\title{
Phylogenetic position of Javan banteng (Bos javanicus javanicus) from conservation area in Java base on mtDNA analysis
}

\author{
MARYATUL QIPTIYAH ${ }^{1,2, \bullet}$, SATYAWAN PUDYATMOKO ${ }^{2, \bullet \bullet}$, AYPBC WIDYATMOKO ${ }^{2}$, \\ ILG NURTJAHJANINGSIH ${ }^{2}$, MUHAMMAD ALI IMRON ${ }^{2}$ \\ ${ }^{1}$ Faculty of Forestry, Universitas Gadjah Mada University. J1 Agro No.1, Bulaksumur, Sleman 55281, Yogyakarta, Indonesia. \\ Tel.: +62-274- 550541, ^email: maryatulqiptiyah@biotifor.or.id; ^v spudyatmoko@ugm.ac.id \\ ${ }^{2}$ Center for Biotechnology and Tree Improvement Research and Development. Jl. Palagan Tentara Pelajar Km 15, Purwobinangun, Pakem, Sleman \\ 55582, Yogyakarta, Indonesia
}

Manuscript received: 2 September 2019. Revision accepted: 28 October 2019.

\begin{abstract}
Qiptiyah M, Pudyatmoko S, Widyatmoko AYPBC, Nurtjahjaningsih ILG, Imron MA. 2019. Phylogenetic position of Javan banteng (Bos javanicus javanicus) from conservation area in Java base on mtDNA analysis. Biodiversitas 20: 3352-3357. Two of three subspecies of banteng (B. javanicus) can be found in Indonesia, namely B. j. lowi and B. j. javanicus. The taxonomic assignment of the two subspecies is still in the discussion researchers currently. One of the reproductive characters of members the Bovidae family, including the banteng, is known to have interbreeding ability between species and can produce fertile offspring. In some places, there exist grazing cattle near or in the banteng's natural habitat. This phenomenon aimed to provide banteng mates with cows, which later they will breed high-quality offsprings. Regarding interbreeding capability, this condition can be a threat to the genetic purity of wild banteng. The main objectives of this study were to identify the phylogenetic position of Javan banteng from conservation areas in Java in relation to the other taxon and detect their genetic purity. We analyzed 28 cytochrome b and d-loop region sequences of Javan banteng from feces materials of four conservation areas (Ujung Kulon National Park, Alas Purwo National Park, Meru Betiri National Park, and Baluran National Park). We compared our data with reference sequences data of the other Bovidae species and Capra hircus as outgroup. The reference data was taken from NCBI, and they were analyzed using maximum likelihood. The results showed that Javan banteng was in a different group from other taxa. Separation of subspecies B. j. javanicus and B. j. lowi occurred circa 1.25 mya. The results from this study suggested that there is no indication of genetic introgression between Javan banteng and the (domesticated) cattle.
\end{abstract}

Keywords: Bovidae, cytochrome b, d-loop, Javan banteng

\section{INTRODUCTION}

Banteng (Bos javanicus d'Alton, 1826) is divided into three subspecies, namely, Bos javanicus birmanicus that is found in mainland of Asia; Bos javanicus lowi which is scattered in many parts of Kalimantan mainland; and Bos javanicus javanicus which is found in some locations in Java island (Hogerwerf 1970; Gardner et al. 2014; Castello 2016). The current distribution of Javan banteng (B. $j$. javanicus) in the Java island can be grouped into two regions, namely, in the western region of Java, i.e., Ujung Kulon National Park (UKNP) and the eastern region, i.e., Meru Betiri National Park (MBNP), Baluran National Park (BNP) and Alas Purwo National Park (APNP) (Hakim et al. 2015). The Bornean banteng (B. j. lowi) spread mostly in Kutai NP and Kayan Mentarang NP.

In general, wild banteng is often found in semi-open forests with grasslands (Garsetiasih 2013; Matsubayashi et al. 2014; Gardner et al. 2014) and mineral source such as shoreline or saltlick sources area (Hoogerwerf 1970; Whitten et al. 1996; Hedges and Meijaard 1999; Imron et al. 2016). The taxonomic position of two banteng groups (B. j. javanicus and B. j. lowi) from Indonesia is still unclear (Timmins et al. 2008). Based on morphological characters, the body size of the Bornean banteng was smaller than the other subspecies (Hogerwerf 1970; Matsubayashi et al. 2014; Castello 2016).

Several habitats of banteng in conservation areas in the Java island has a serious threat, such as, the existence of settlements that are too close to the protected area (Sutarno and Setyawan 2016). Such situations occur in Meru Betiri $\mathrm{NP}$, which has plantation areas and settlements within (enclaves), and it is also used as a Javan banteng habitat (Garsetiasih 2012). In BNP there are some people raising livestock without cage and using grazing areas in the territory of the national park (Pudyatmoko et al. 2018). Subspecies B. j. birmanicus are found to lived sympatrically with gaur (B. frontalis) and kouprey (B. sauveli) groups in Cambodia (Hassanin and Ropiquet 2007). Indonesia's Bornean banteng (B. j. lowi) in feeding ground of Long Tua, Kayan Mentarang NP, North Kalimantan, have been reported to live with cattle until 1992 (Hedges and Meijard 1999). Such condition of wild banteng habitats that were being too close to feral herd domestic cattle raises a concern about the genetic purity of banteng. This concern is supported by the fact that the Bovidae group has excellent potential for interbreeding between species in the same genus (Martojo 2012). The Cambodian banteng (B. j. birmanicus) have interbred with domesticated cattle around the area, and it resulted in 
kouprey, B. sauveli (Hassanin and Ropiquet 2007).

Mitochondrial DNA (mtDNA) is genetic maternal inheritance, and it can be used as a determinant of organism evolution by genetic position (Winaya 2010) and also determine the genetic purity of a species (Allendorf and Luikart 2007). Information about the banteng phylogenetic position and their genetic purity have been published, but these studies used Cambodian and Bornean banteng only (Hassanin and Ropiquet 2007; Matsubayashi et al. 2014; Gardner 2014). As we know, the previous study used Javan banteng from natural populations as samples were not complete yet. The samples that used before have been carried out such as in Alas Purwo NP or Meru Betiri NP only (Wisesa et al. 2012; Sawitri et al. 2014). The other previous research that also using noninvasive samples of Javan banteng had purposed to identify haplotype of banteng and analyzed only on one mtDNA region (Qiptiyah et al. 2019). This study aims to analyze that $B . j$. javanicus from the conservation area has a different phylogenetic position from $B . j$. lowi and also to identify the genetic purity of the Javan banteng in its natural habitat from the genetic introgression of cattle.

\section{MATERIALS AND METHODS}

\section{Study area}

Samples of feces as the genetic material of banteng were obtained from Java, i.e. UKNP of West Java, BNP, APNP, and MBNP of East Java (Figure 1). A sampling of genetic material at UKNP and APNP was carried out mainly in grazing fields that are still frequently visited by banteng, namely: Cigenter and the Cidaon feeding ground (UKNP); and Sadengan feeding ground and aircraft runways for patrolling (APNP). Meanwhile, in Baluran NP and Meru Betiri NP, the collection of genetic material was done by exploring around the drinking site due to the difficulty of finding banteng. Banteng at Meru Betiri NP left the Pringtali feeding ground due to a land-use conflict with the community so that people drove away wildlife, including banteng, by firing fireworks every night.

Samples for molecular work come from the epithelial cells of banteng's intestine that have decayed along with the discharge of feces. Epithelial cells are generally found on the outside of the feces because the outer surface of feces touches the intestinal wall. The sample was taken from the outside surface of the fresh stool. Stool that has been too long exposed to the sun is at risk of DNA damage (Waits and Paetkau 2005). However, some of the samples were somewhat dried up but could still be used for DNA analysis, even though the concentration was small.

The sample collection was carried out during drought or low rainfall intensity to avoid degradation of the epithelial cell into feces so that banteng DNA could not be obtained successfully (Farrel et al. 2000; Lampa et al. 2008; Brinkman et al. 2010). The samples were collected in September 2015 and September 2016. The samples were inserted into the fecal tube and preserved with absolute ethanol. Transporting the samples process was conducted at $\pm 4^{\circ} \mathrm{C}$ to keep the freshness of samples and to avoid DNA degradation. The DNA analysis was carried out at the Molecular Genetic Laboratory of Center for Forest Biotechnology and Tree Improvement Research and Development, Yogyakarta, Indonesia.
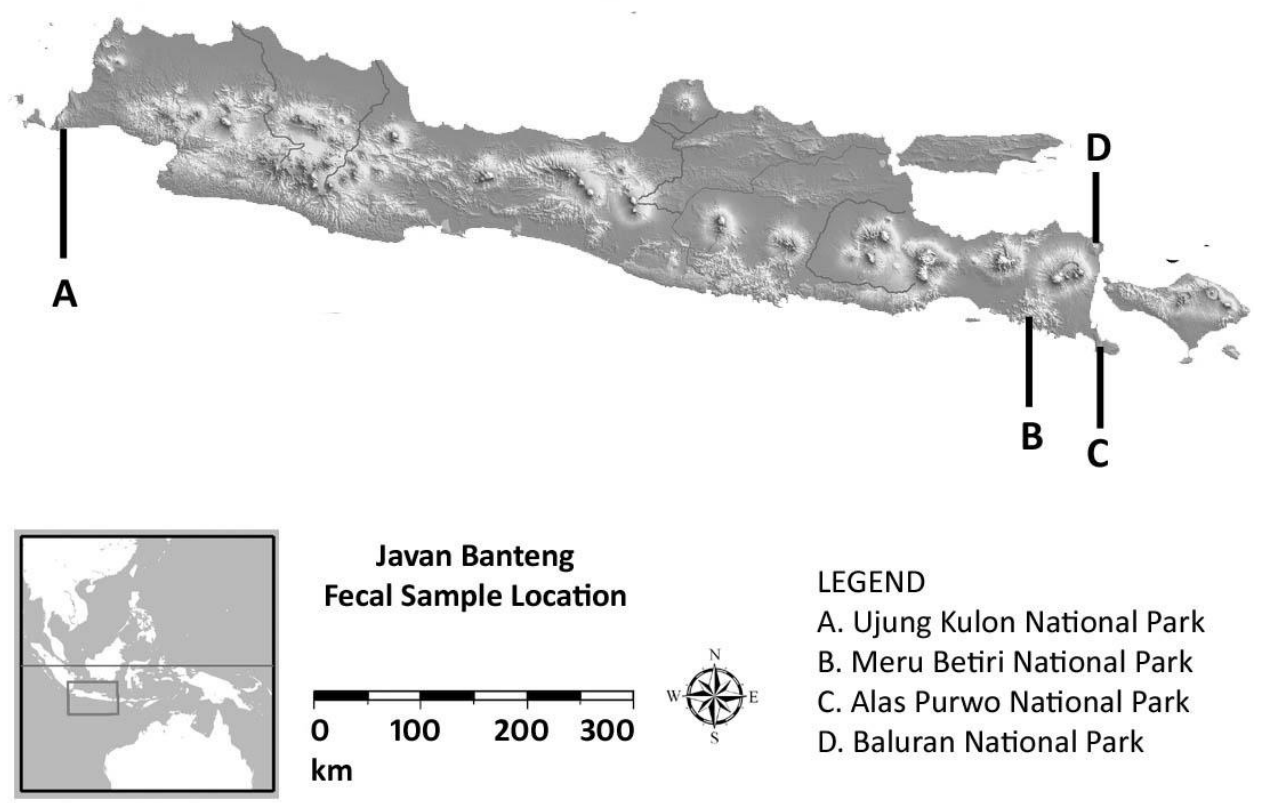

Figure 1. Map of geographical position of four national parks in Java where sampling of Javan banteng's genetic material sampling for this study. 
Table 1. GenBank accession number of reference sequences (Matsubayashi et al. 2014; Gardner 2014)

\begin{tabular}{|c|c|c|}
\hline \multirow[b]{2}{*}{$\begin{array}{l}\text { Species name and } \\
\text { code }\end{array}$} & \multicolumn{2}{|c|}{ GenBankaccession number } \\
\hline & $\begin{array}{c}\text { Cytochrome b } \\
\text { region }\end{array}$ & d-loop region \\
\hline B. javanicus lowi $\mathrm{H} 1$ & $\mathrm{AB} 703046$ & AB703048 \\
\hline B. javanicus lowi $\mathrm{H} 2$ & AB703047 & AB703049 \\
\hline $\begin{array}{l}\text { B. javanicus } \\
\text { birmanicus } \text { CKM4 }\end{array}$ & EF685912 & EF693804 \\
\hline $\begin{array}{l}\text { B. javanicusbirmanicus } \\
\text { CKM } 23\end{array}$ & EF685913 & EF693805 \\
\hline Bos gaurus $01^{*}$ ) & GU324987 & GU324987 \\
\hline Bos indicus $\left.01^{*}\right)$ & AY126697 & AY126697 \\
\hline Bos sauveli $\left.02^{*}\right)$ & GU256940 & GU256940 \\
\hline B.taurus & FJ971088.1 & FJ971088.1 \\
\hline B. grunniens & KM733416.1 & KM733416.1 \\
\hline B. sauveli & AY689189 & AY689189 \\
\hline Bison bison bison & JPYT01158469.1 & JPYT01158469.1 \\
\hline Capra hircus & $\mathrm{NC} 005044$ & NC005044 \\
\hline
\end{tabular}

\section{Procedures}

DNA isolation was started by taking the material of about 0.5 grams from the outside surface of the feces, using QiaAmp Stool Mini Kit from QIAGEN. The DNA isolation was following the modified protocols in the ASL buffers incubation section (Mondol et al. 2009; Gardner 2004; Qiptiyah et al. 2019). DNA Amplification of the dloop region used BovmtFP primer (5' CAT CTA AAA CGG TCC ATT CTT TTC TC $3^{\prime}$ ) and BovmtBP primer (5' ACT CAT CTA GGC ATT TTC AGT 3'), following the previous research that had used these primers for Bali cattle (Wisesa et al. 2012). In the cytochrome $b$ region, we used $1 \mathrm{~F}$ primer, with the nucleotide sequence of $5^{\prime}$ ATC CTC ACA GTA CTA TTC CTA GCA ATA CA 3' and 1R, with nucleotide sequence 5' GGT AAG GGT TGC TTT ATC TGA GAA TC 3', that also followed the previous research (Gardner 2014; Qiptiyah et al. 2019).

PCR amplification was using the KAPA Biosystem in the Pro-Flex PCR System machine. The total volume reaction consisted of 50 $\mu \mathrm{l}$, consisting of $50 \mathrm{ng}$ DNA; $1 \mathrm{x}$ KAPA 2G Fast Ready Mix; $0.1 \mathrm{mg}$ of Bovine Serum Albumin (BSA); $0.25 \mathrm{mM}$ for each forward and reverse primer. The optimum PCR condition consisted of predenaturation of DNA for 5 minutes at $94{ }^{\circ} \mathrm{C}$. Furthermore the PCR process was conditioned for 35 cycles of denaturation of DNA for 30 seconds at $94{ }^{\circ} \mathrm{C}$, primer annealing for 30 seconds at $55^{\circ} \mathrm{C}$ and extension for 1 minute 30 seconds at $72^{\circ} \mathrm{C}$. The PCR processes were terminated by the final extension for 7 minutes at $72^{\circ} \mathrm{C}$. The amplicon were visualized on $1.5 \%$ agarose gel electrophoresis at $120 \mathrm{~V}$ voltage for 1 hour. Gels were imaged using BioRad UV GelDoc. The amplicons were then purified and sequenced partially using the Big Dye Terminator v3.1 Cycle Sequencing Kit and ABI PRISM 3730xl Genetic Analyzer (Applied Biosystem, USA) machine in First BASE Laboratories. The results sequences were compared to the nucleotide sequence database from the NCBI GenBank using BLAST methods to confirm species identity.

\section{Data analysis}

Both the d-loop and cytochrome b region partial sequences were aligned with the reference sequences (Table 1) used CLUSTAL W in BioEdit 7 software (Hall 1999). The analysis of the phylogenetic tree used maximum likelihood, with 1000 bootstrap. The molecular time divergence analysis used RelTime method with specific time constraint among Bison bison bison and $B$. grunniens (their divergence time 3.89 to 5.53 mya), that accorded to previous research (Hassanin and Ropiquet 2007; Gardner 2014). The genetic distance of this study was calculated using Tamura-Nei model (Tamura and Nei 1993). Both the phylogenetic tree, molecular time divergence, and genetic distance analyses were carried out using MEGA 7 software (Kumar et al. 2016). The outgroup that used in this analysis was Capra hircus (NC005044, Gardner 2014).

\section{RESULTS AND DISCUSSION}

The results from multiple alignments of the entire sample found that the sequence obtained in the cytochrome b region was $345 \mathrm{bp}$, and in the d-loop region was $373 \mathrm{bp}$, with the total base length was of $718 \mathrm{bp}$. The nucleotide compositions were Adenin (30.2\%) with the highest frequency and $\mathrm{G}(16.2 \%)$ with the lowest frequency.

Based on the analysis of mitochondrial DNA in the cytochrome $\mathrm{b}$ and d-loop region, all the Javan banteng sequences from four natural populations were in one group (Figure 2). Our phylogenetic tree in this study is not identical to phylogenetic trees in other studies (Hassanin and Ropiquet 2007; Matsubayashi et al. 2014; Gardner 2014). Based on the phylogenetic tree result in this study, the Javan banteng is more related to $B$. indicus compared to other members of the subspecies, such as $B$. j. lowi and B. j. birmanicus. This result is not consistent with the results from previous studies, which found that B. j. javanicus is separated from $B$. indicus (Matsubayashi et al. 2014; Gardner 2014). A possible explanation for the difference is because each researcher analyzed using a shorter sequence, that resulted in a different phylogenetic inference. Arif et al. (2012) stated that the use of complete genomes of mitochondrial DNA produced higher resolution and more stable, compared to the use of single gene or shorter sequences.

Differences in phylogenetic tree are also found in similar studies, as a result of the selection of different mtDNA region or the use of different analytical algorithms (Hasanin and Ropiquet 2007). Based on the cytochrome b region and sub-unit II of the cytochrome c oxidase (CO2), the Javan banteng is more related to $B$. frontalis when it is analyzed using Bayesian analyzers and more related to $B . j$. gaurus, $B$. j. sauveli and B. j. birmanicus if it is analyzed using the maximum parsimony approach (Hassanin and Ropiquet 2007). Differences in the phylogenetic tree can also occur due to misleading in the analysis as a result of extreme genetic drift (Allendorf and Luikart 2007; Matsubayashi et al. 2014), making it possible to occur in the analysis of Javan banteng which is in small populations status (Pudyatmoko 2007). 


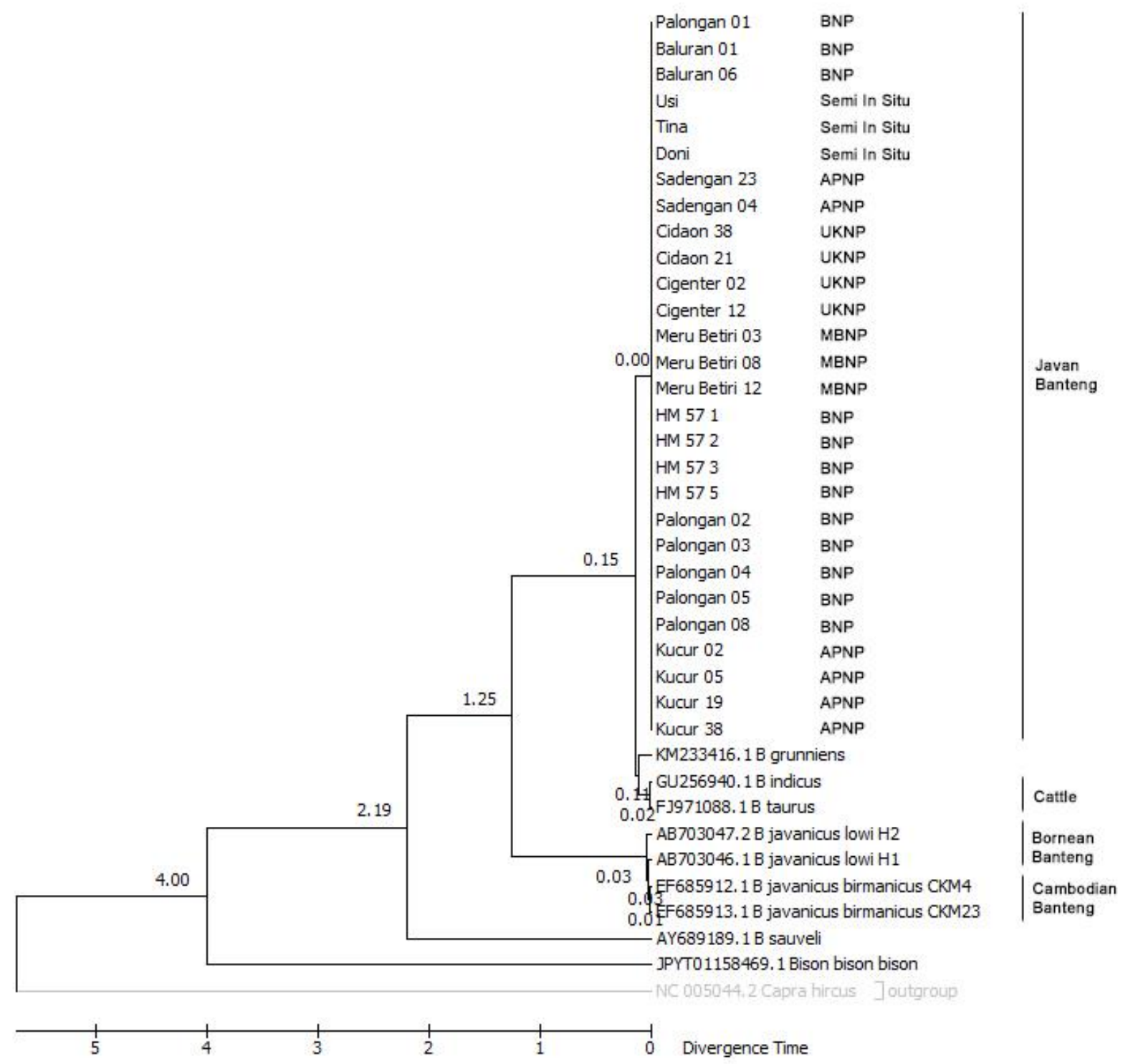

Figure 2. Phylogenetic position of Javan banteng, Bornean banteng, and the other Bos base on mitochondrial DNA. The phylogenetic tree was constructed using maximum likelihood, with 1000 bootstrap. The molecular time divergence analysis calculated with the RelTime method using one calibration point ranging between 3.89 to 5.53 between Bison bison bison and B. grunniens. Both analyzes conducted using MEGA 7

The results of this current study identify the molecular time divergence between the Javan banteng and the Bornean banteng is about 1.25 mya. This value is lower than the molecular time divergence identified in previous studies, which is circa 1.76 mya (Gardner 2014). The Javan banteng is believed to be older than the Bornean banteng, which is found about 10 kilos years ago (kya) based on ancient records in a Cave in East Kalimantan (Gardner 2014). This statement is contradicted to the records of Hogerwerf (1970), who stated that the Javan banteng is found at $1000 \mathrm{BC}$ in the Sampung Cave, Ponorogo. However, the age of the older Javan banteng makes sense if it is associated with the fossils of early Banteng (Bibos palaesondaicus) which are found in the Trinil area, Central
Java and is assumed to have lived about one million years ago (mya) (Whitten et al. 1996).

The phylogenetic position of the Javan banteng is separated from the other subspecies (B. j. lowi and B. $j$. birmanicus). The results of the character comparison analysis between the DNA sequences from the three subspecies (without out-group) noted that there were $32.73 \%$ characters that varied, which was equal to 235 characters from the observed characters (718 bp). The separation of the three banteng subspecies found in this study is consistent and more corroborative to the findings of previous studies, which also illustrates that the phylogenetic position between three banteng subspecies in mainland Asia, Borneo and Java is separated in 
phylogenetic trees (Hassanin and Ropiquet 2007; Matsubayashi 2014; Gardner 2014).

The fact about differences in phylogenetic position and molecular time distance is sufficiently far enough to prove that the Javan banteng (B. javanicus) is taxonomically different from the Bornean banteng $(B . j$. lowi) and the Cambodian banteng (B. j. birmanicus) at the subspecies level. Thus, it can be concluded that the debate about the certainty of taxonomic status, especially on the Javan banteng and the Bornean banteng, both of which live in Indonesia, is not over yet. The conservation implications that can be elaborated are that in its management, the two subspecies of banteng in Indonesia must be managed separately even though they belong to the same species.

Javan banteng is a member of the Bovidae group, which is known to be able to interbreed with other closely related species (Nijman et al. 2003). With this ability, the Bovidae group often gets high intervention from humans, especially in terms of distribution and breeding. One example of intervention in the Bovidae group, including the banteng is Javan banteng, which was utilized as the broodstock of Balinese cattle, in other words, Balinese cattle are the result of the domestication of the Javan banteng (Nijman et al. 2003; Martojo 2012). Another fact related to the potential of the Javan banteng as the parent of cattle breeds in Indonesia is that Madura cattle are known to carry the character of banteng mtDNA with similarities of $99.5 \%$ (Nijman et al. 2003).

Information on the potential of Javan banteng as the ancestor for Bali cattle and their ability to interbreed between species in the Bovidae group triggers concern about the genetic purity of Javan banteng in the natural population (Sutarno and Setyawan 2016). Furthermore, the fact that there were cattle that feed on grazing land in the conservation area also adds to concern about the genetic introgression by cattle on the Javan banteng in the natural population. Pudyatmoko et al. (2018) found around 1700 individuals of cattle use part of Baluran NP territory for their grazing land.

Regarding the genetic purity of the Javan banteng, the results of this study show that the whole Javan banteng $(B$. $j$. javanicus) sequences are in a different group from the species of cattle that are commonly raised in Indonesia $(B$. indicus and $B$. taurus). Differences in genetic characteristics between the Javan banteng and the other two species of cattle are only 46 nucleotide characters or $6.41 \%$ of the total character of the examined nucleotide character. This founding shows that based on the sequences of mitochondrial DNA in the cytochrome-b and d-loop region, the Javan banteng in the natural population still has genetically pure or indicate no genetic introgression from domestic cattle. This statement is following the species concept that used genetic distance (divergence) of 5\% to determine species in mammals (Baker and Bradley 2006). The finding of genetic purity Javan banteng is also consistent with the genetic purity of Bornean banteng which lives in Sabah that is believed to has pure genetics still, and there had been no influence of genetic introgression from domesticated cattle, although they were found to coexist (Matsubayashi et al. 2014; Gardner 2014).
The Javan banteng is proved to have no interaction with cattle in the natural population due to various causes. Banteng that was life in Ujung Kulon NP has no interaction with cattle because their habitat is very far from human settlement and activities. Banteng is known to be shy and tends to stay away from the location of human activity. In Alas Purwo NP, Javan banteng feels comfort at a distance of $15 \mathrm{~km}$ from roads, although it was not corroborative evidence (Imron et al. 2016). In other conservation areas, the Javan banteng was investigated to have no interaction with cattle that live in the Baluran NP. The claim is based on the previous research that reported that the banteng in Baluran NP has never been captured by camera traps at the area occupied by settlement and livestock/ AOL (Pudyatmoko 2017). In Meru Betiri NP, which has enclaves area inside, the banteng habitat has never been reported to be grazed by cattle. According to the local community, they believe that although their residential area overlaps with banteng habitat, there is no direct interaction between the Javan banteng and local cattle. They have never let the cattle use grazing area in the national park and keep their cattle in the captivity.

This study also found a small genetic distance between the Javan banteng and two species of cattle (B. indicus and $B$. taurus), which were 0.048 and 0.054 , respectively. These results were equivalent to the previous research that found that genetic distance between Javan banteng and $B$. indicus was 0.055. Meanwhile, the genetic distance between Javan banteng and B. taurus was 0,052 , based on the d-loop region (Wisesa et al. 2012). Concerning that, the precautionary principle needs to be taken to maintain the genetic purity of the remaining Javan banteng. Nijman et al. (2003) stated that the opportunities for interbreeding would be an increase in species that have close genetic relationships and live in the same habitat. His statement had implicated there is a need for more intensive supervision on the areas that were used as shared habitats between Javan banteng and cattle as in Baluran NP. The previous research found that the area that was occupied by settlement and livestock, including cattle, is 5600 ha or $22 \%$ of the total terrestrial in Baluran NP (Pudyatmoko 2017; Pudyatmoko et al. 2018).

\section{ACKNOWLEDGEMENTS}

We would like to thank the Center for Forest Biotechnology and Tree Improvement Research and Development, Yogyakarta, Indonesia for the financial research support; staffs of Ujung Kulon NP, Alas Purwo NP, Meru Betiri NP Baluran NP and Copenhagen Zoo for the support in fecal sample collection; Rekognisi Tugas Akhir (RTA) Program at Gadjah Mada University for publishing support. We are grateful to the anonymous reviewers for the constructive suggestions of the manuscript. 


\section{REFERENCES}

Allendorf F, Luikart GH. 2007. Conservation and the Genetics of Populations. Blackwell Publishing, UK.

Arif IA, Bakir MA, Haseeb AK. 2012. Inferring the phylogeny of Bovidae using mitochondrial DNA sequences: Resolving Power of individual genes relative to complete genomes. Evolut Bioinformatics 8: 139150. DOI: $10.4137 / \mathrm{EBO} . \mathrm{S} 8897$

Baker RJ, Beadley RD. 2006. Speciation in mammals and the genetic species concept. J Mamm 87 (4): 643-662.

Brinkman TJ, Schwartz MK, Person DK, Pilgrim KL, Hundertmark KJ 2010. Effects of time and rainfall on PCR success using DNA extracted from deer fecal pellets. Conserv Genet 11: 1547-1552. DOI $10.1007 / \mathrm{s} 10592-009-9928-7$

Castello JR. 2016. Bovids of the World. Antelopes, Gazelles, Cattle, Goats, Sheep, and Relatives. Princeton University Press, Princeton.

Farrel LA, Roman J, Sunquist ME. 2000. Dietary separation of sympatric carnivores identified by molecular analysis of scats. Mol Ecol 9 : 1583-1590.

Gardner PC. 2014. The natural history, non-invasive sampling, activity patterns, and population genetic structure of the Bornean banteng Bos javanicus lowi in Sabah, Malaysian Borneo. [Dissertation]. Cardiff University, UK.

Gardner RCD, de Lange PJ, Keeling DJ, Bowala T, Brown HA, Wrigh SD. 2004. A late quarternary phylogeography for Metrosideros (Myrtaceae) in New Zeland inferred from chloroplast DNA haplotypes. Biol J Linn Soc 83: 399-412.

Garsetiasih R, Alikodra HS, Soekmadi R, Bismark M. 2012. Potensi dan produktivitas habitat pakan banteng (Bos javanicus d'Alton 1832) di padang perumputan pringtali dan kebun Pantai Bandealit Taman Nasional Meru Betiri Jawa Timur. Jurnal Konservasi Hutan dan Pelestarian Alam 9 (2): 113-123. [Indonesian]

Garsetiasih R. 2013. Daya dukung padang perumputan banteng (Bos javanicus D Alton, 1823) : studi kasus di Sadengan dan Sumber Gedang, Jawa Timur. Jurnal Pemuliaan Hutan dan Konservasi Alam 10 (2): 229-240. [Indonesian]

Hall TA. 1999. BioEdit: a user-friendly biological sequence alignment editor and analysis program for Windows 95/98/NT. Nucleic Acids Symp Ser 41: 95-98.

Hakim L, Guntoro DA, Waluyo J, Sulastini D, Hartanto L, Nakagoshi N. 2015. Recent status of banteng (Bos javanicus) conservation in Eas Java and its perspectives on ecotourism planning. J Trop Life Sci 5 (3): 152-157

Hassanin A, Ropiquet A, Cornette R, Tranier M, Pfeffer P, Candegabe P, Lemaire M. 2006. Has the kouprey (Bos sauveli Urbain, 1937) been domesticated in Cambodia? C R Biol 329 (2): 124-35. DOI: 10.1016/j.crvi.2005.11.003

Hassanin A, Ropiquet A. 2007. What is the taxonomic status of the Cambodian banteng, and does it have close genetic links with the kouprey? J Zool 271: 246-252. DOI: 10.1111/j.14697998.2006.00272.x

Hedges S, Meijaard E. 1999. Reconnaissance survey for banteng (Bos javanicus) and banteng survey methods training project, Kayan Mentarang National Park, East Kalimantan, Indonesia, WWF Indonesia, and CIFOR, Bogor.

Hoogerwerf A. 1970. Udjung Kulon, The Land of the Last Javan Rhinoceros: With Local and General Data on the Most Importan Faunal Species and Their Preservation in Indonesia. E.J. Brill, Leiden.

Imron MA, Hastuti HM, Satria RA, Ashari M, Rudijanta, Nurvianto S, Subeno, Pudyatmoko S. 2016. The use of habitat suitability index map for designing population monitoring of banteng (Bos javanicus) in Alas Purwo National Park-East Java-Indonesia. Asian J Conserv Biol 5 (1): 31-39.
Kumar S, Stecher G, Tamura K. 2016. MEGA7: Molecular evolutionary genetics analysis version 7.0 for bigger datasets. Mol Biol Evol 33 (7): $1870-1874$

Lampa S, Gruber B, Henle K, Hoehn M. 2008. An optimization approach to increase DNA amplification success of otter feces. Conserv Genet 9: 201-210. DOI 10.1007/s10592-007-9328-9

Martojo H. 2012. Indigenous Bali cattle is most suitable for sustainable small farming in Indonesia. Reprod Dom Anim 47 (Suppl. 1): 10-14. DOI: $10.1111 / \mathrm{j} .1439-0531.2011 .01958 . \mathrm{x}$

Matsubayashi H, Hanzawa K, Kono T, Ishige T, Gakuhari T, Lagan P, Sunjoto I, Sukor JRA, Sinun W, Ahmad AH. 2014. First molecular data on Bornean banteng Bos javanicus lowi (Cetartiodactyla, Bovidae) from Sabah, Malaysian Borneo. Mammalia 78 (4): 1-9. DOI: 10.1515/mammalia-2013-0052

Mondol S, Karanth KU, Kumar NS, Gopalaswamy AM, Andheria A, Ramakrishan U. 2009. Evaluation of non-invasive genetic sampling methods for estimating tiger population size. Biol Conserv 142 (10): 2350-2360. DOI: 10.1016/j.biocon.2009.05.014

Nijman IJ, Otsen M, Verkaar ELC, de Ruijter C, Hanekamp E, Ochieng JW, Shamshad S, Rege JEO, Hanotte O, Barwegen MW, SulawatiT, Lenstra JA, 2003. Hybridization of banteng (Bos javanicus) and zebu (Bos indicus) revealed by mitochondrial DNA, satellite DNA, AFLP, and microsatellites. J Heredity 90: 10-16

Pudyatmoko S, Djuwantoko, Sabarno Y. 2007. Evidence of banteng (Bos javanicus) decline in Baluran National Park, Indonesia. J Biol Sci 7 (6): 854-859. DOI: $10.3923 /$ jbs.2007.854.859

Pudyatmoko S. 2017. Free-ranging livestock influence species richness, occupancy, and daily behavior of wild mammalian species in Baluran National Park, Indonesia. Mamm Biol 86: 33-41. DOI: 10.1016/j.mambio.2017.04.001

Pudyatmoko S, Budiman A, Kristiansen S. 2018. Towards sustainable coexistence: People and wild mammals in Baluran National Park, Indonesia. J For Policy Econ 90: 151-159.

Qiptiyah M, Pudyatmoko S, Widyatmoko AYPBC, Imron MA, Nurtjahjaningsih ILG. 2009. Cytochrome b mitochondrial DNA characteristic from non-invasive samples of wild population Javan Banteng (Bos javanicus D'Alton, 1823). Biodiversitas 20 (2): 350355. DOI: $10.13057 /$ biodiv/d200207

Sawitri R, Zein MSA, Takandjandji M, Rianti A. 2014. Keragaman genetik banteng (Bos javanicus d'Alton) dari berbagai lembaga konservasi dan Taman Nasional Meru Betiri. Jurnal Hutan dan Konservasi Alam 11: 155-159. [Indonesian]

Sutarno, Setyawan AD. 2016. Review: The diversity of local cattle in Indonesia and the effort to develop superior indigenous cattle breeds. Biodiversitas Volume 17 Number 1: 275-295. DOI: 10.13057/biodiv/d170139

Tamura K, Nei M. 1993. Estimation of the number of nucleotide substitutions in the control region of mitochondrial DNA in human and chimpanzees. Mol Biol Evol 10: 512-526.

Timmins RJ, Duckworth JW, Hedges S, Steinmetz R, Pattanaviboo A. 2008. Bos javanicus. In: IUCN Red List of threatened species. Available at : www.iucnredlist.org/ details/biblio/2888/0.

Waits LP, Paetkau D. 2005. Noninvasive genetic sampling tools for wildlife biologists: A review of applications and recommendations for accurate data collection. J Wildl Manag 69 (4): 1419-1433.

Whitten T, Soeriaatmaja RE, Afiff SA. 1996. The Ecology of Java and Bali. The Ecology of Indonesia Series. Volume II. Periplus Editions, Hongkong.

Winaya A. 2010. Variasi genetic dan hubungan filogenetik populasi sapi lokal Indonesia berdasarkan penciri molekuler DNA mikrosatelit kromosom Y dan gen cytochrome B. [Disertasi]. Sekolah Pasca Sarjana. IPB. Bogor. [Indonesian]

Wisesa AANG, Pemayun TGO, Mahardika IGNK. 2012. Analisis sekuens D-Loop DNA mitokondria sapi Bali dan banteng dibandingkan dengan bangsa sapi lain di dunia. Indones Med Vet 1 (2): 281-292. [Indonesian] 